\title{
OPTIMASI PENEMPATAN OPTIMAL PERALATAN SVC DENGAN METODE ALGORITMA GENETIKA
}

\author{
Zulfahri $^{1}$, Elvira Zondra ${ }^{2}$ \\ ${ }^{1,2}$ Program Studi Teknik Elektro, Fakultas Teknik, Universitas Lancang Kuning \\ Jl. Yos Sudarso km. 8 Rumbai, Pekanbaru, Telp. (0761) 52324 \\ Email: zulfahri@unilak.ac.id, elviraz@unilak.ac.id
}

\begin{abstract}
ABSTRAK
Sistem kelistrikan membutuhkan kondisi tegangan yang stabil. Salah satu metode yang dipakai untuk menjaga tegangan tersebut adalah dengan penempatan peralatan kompensator VAr secara optimal. Tujuan dari penempatan peralatan ini adalah untuk memperbaiki tegangan dalam kondisi undervoltage atau overvoltage. Pada saat terjadi undervoltage dan overvoltage perlu dilakukan penambahan dan pengurangan daya reaktif. Salah satu alat yang berfungsi untuk melakukan penambahan dan pengurangan daya reaktif adalah Static Var Compensator (SVC), komponen yang terdiri dari reaktor dan kapasitor yang diatur oleh thyristor. Metode yang digunakan untuk penentuan penempatan optimal peralatan SVC pada penelitian ini adalah Algoritma Genetika. yang terinspirasi dari teknik pencarian heuristik yang didasarkan pada gagasan evolusi seleksi alam dan genetik. GA dapat melakukan perbaikan tegangan pada sistem dengan injeksi SVC. Hasil simulasi dari metode yang diusulkan dengan injeksi kompensasi SVC sebesar 70 Mvar dapat menaikkan tegangan terendah 0.850 pu menjadi $0.942 \mathrm{pu}$, sehingga profil tegangan bus akan dapat dijaga pada nilai-nilai yang diijinkan sehingga kontinuitas serta kualitas operasi sistem tenaga listrik dapat senantiasa dipertahankan.
\end{abstract}

Kata Kunci: SVC, Kestabilan tegangan, Optimal Power flow, algoritma genetika

Electrical systems require stable voltage conditions. One method used to maintain this tension is by placing the VAr compensator equipment optimally. The purpose of placing this equipment is to correct the voltage under undervoltage or overvoltage conditions. In the event of undervoltage and overvoltage, it is necessary to increase and decrease reactive power. One tool that functions to increase and decrease reactive power is the Static Var Compensator (SVC), a component consisting of a reactor and a capacitor regulated by a thyristor. The method used to determine the optimal placement of SVC equipment in this study is the Genetic Algorithm. inspired by heuristic search techniques based on the idea of evolution of natural and genetic selection. GA can improve voltage on systems with SVC injection. The simulation results of the proposed method with SVC compensation injection of 70 Mvar can increase the lowest voltage of 0.850 pu to $0.942 \mathrm{pu}$, so that the bus voltage profile will be maintained at permitted values so that continuity and quality of operation of the electric power system can always be maintained.

Keywords: SVC, voltage stability, optimal power flow, genetic algorithm

\section{PENDAHULUAN}

\subsection{Latar Belakang}

Sistem tenaga listrik membutuhkan kestabilan tegangan. Salah satu sebab yang membuat ketidakstabilan tegangan adalah akibat perubahan kondisi beban dalam jaring sistem sehingga pada sistem tersebut akan terjadi undervoltage dan overvoltage. Untuk menjaga kestabilan tersebut diperlukan suatu kompensasi daya reaktif. Pada saat undervoltage dan overvoltage maka dilakukan penambahan dan pengurangan daya dengan menggunakan Static Var Compensation (SVC).

Static VAR Compensator (SVC) adalah alat yang dapat meghasilkan atau menyerap daya reaktif statis yang dihubungkan paralel dan mempunyai keluaran (output) yang bervariasi untuk menjaga atau mengontrol parameter spesifik dari suatu sistem tenaga listrik. SVC terdiri dari komponen TCR (Thyristor Controlled Reactor), TSC (Thyristor Switched Capasitor) dan Filter Capasitor (FC). Filter harmonisa terhubung paralel dengan TCR yang berfungsi untuk mengatasi harmonisa yang dihasilkan oleh TCR. Prinsip kerja SVC adalah dengan mengatur sudut penyalaan thyristor, sehingga dapat mengatur keluaran daya reaktif dari SVC. Tujuan utama pemasangan SVC adalah untuk menjaga perubahan tegangan pada bus dalamjaringan transmisi dan distribusi serta untuk meningkatkan stabilitas tegangan dengan cara menyuntikkan daya reaktif dengan mengendalikan arus kapasitif atau arus induktif [5]. 
Pada sistem jaring tenaga listrik, SVC digunakan secara luas untuk mengganti kerugian daya reaktif, mengurangi rugi-rugi energi, mengatur tegangan dan meningkatkan keamanan pada sistem. Permasalahannya adalah bagaimana penentuan SVC dialokasikan dan berapa besarnya dalam sistem transmisi atau distribusi tenaga listrik. Parameter-parameter batasan tegangan, range kerja SVC yang bervariasi untuk beban diperlukan dan dipertimbangkan dengan seksama, sehingga permasalahan menjadi sangat kritis. Untuk menentukan posisi penempatan atau pemasangan SVC yang tepat, maka digunakan metode optimasi dengan menggunakan fungsi obyektif berdasarkan parameter rugi-rugi daya (Ploss), rugi-rugi tegangan (Vloss) dan kapasitas SVC [5].

\section{METODE PENELITIAN}

\subsection{Gambaran Umum}

Berdasarkan permasalahan diatas, peneliti akan melakukan pengujian data dari sistem 30 bus IEEE. menggunakan algoritma genetika, secara umum ditunjukkan pada Gambar 1. Flowchart Algoritma Komputasi dari Metode yang Diusulkan

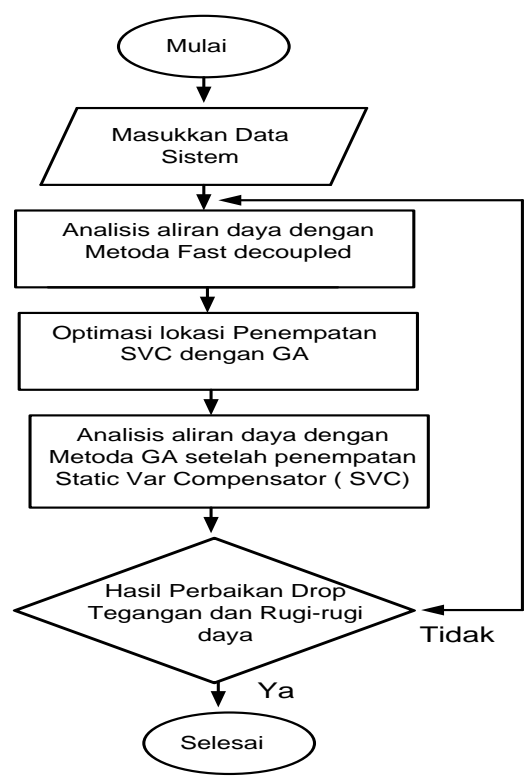

Gambar 1. Flowchart Algoritma Komputasi dari Metode yang Diusulkan

\subsection{Analisis Aliran Daya Fast decoupled}

Untuk menyelesaikan masalah aliran daya telah digunakan berbagai metode, cara yang paling sering digunakan sebagai salah satu materi dasar studi aliran daya adalah dengan membentuk matriks admitansi (Y) bus. Selanjutnya matriks tersebut dikerjakan dengan iterasi, metode dasar yang akan dibahas dalam penelitian ini adalah Fast decoupled dengan simulasi aliran beban berbantuan program Matlab R2016a

\subsection{Penyelesaian dengan Metode Fast decoupled}

Karakteristik yang menarik dari pengoperasian sistem tenaga dalam kondisi tunak adalah ketergantungan antara daya nyata dengan sudut fasa tegangan bus dan antara daya reaktif dengan magnitude tegangan bus. Dalam kondisi ini, adanya perubahan yang kecil pada magnitude tegangan tidak akan menyebabkan perubahan yang berarti pada daya nyata.

Sedangkan perubahan kecil pada sudut tegangan fasa tidak akan menyebabkan perubahan berarti pada daya reaktif. Ini dapat dibuktikan pada pendekatan pendekatan dilakukan untuk menyatakan teterkaitan antara P dan $\delta$ serta antara Q dan V.

Dengan menggunakan bentuk koordinat kutub maka solusi permasalahan diperoleh yaitu dengan cara mengasumsikan elemen-elemen sub matriks $\mathbf{J}_{2}$ dan $\mathrm{J}_{3}$ dalam matriks Jacobi adalah nol.

$$
\begin{aligned}
& {\left[\begin{array}{l}
\Delta P \\
\Delta \boldsymbol{Q}
\end{array}\right]=\left[\begin{array}{cc}
J_{1} & 0 \\
0 & J_{1}
\end{array}\right]\left[\begin{array}{c}
\Delta \delta \\
\Delta V
\end{array}\right]} \\
& \Delta P=J_{1} \Delta \delta\left[\frac{\partial P}{\partial \delta}\right] \Delta \delta \\
& \Delta Q=J_{4} \Delta|V|\left[\frac{\partial Q}{\partial|V|}\right] \Delta|V|
\end{aligned}
$$

dipersamaan diatas dapat dilihat bahwa apabila pada pembentukan daya aktif faktor yang menentukan adalah sudut tegangan jadi adanya perubahan pada magnitude tegangan tidak mempengaruhi daya aktif. Kondisi sebaliknya diperuntukkan pada persamaan pembentukan daya reaktif yaitu perubahan kecil pada sudut fasa tidak akan menyebabkan perubahan yang berarti pada daya reaktif.

$$
\begin{aligned}
H_{i j} & =\frac{\partial P_{i}}{\partial \delta_{j}}=-\left|V_{i} V_{j} Y_{i j}\right| \sin \left(\delta_{j}-\delta_{i}+\theta_{i j}\right) \\
& =-\left|V_{i} V_{j}\right| \sin \left(\delta_{j}-\delta_{i}\right) \cdot B_{i j}
\end{aligned}
$$

$$
\begin{aligned}
& H_{i j} \frac{\partial P_{i}}{\partial \delta_{j}}\left|V_{i} V_{j} Y_{i j}\right| \sin \theta_{i i}+\sum_{\substack{j=1 \\
j \neq 1}}^{n}\left|V_{i} V_{j} Y_{i j}\right| \sin \left(\delta_{i}-\right. \\
& \left.\delta_{j}+\theta_{i j}\right)=-\left|V_{i}\right|^{2} \cdot B_{i j}-\theta_{i j}
\end{aligned}
$$

Dimana

$$
\begin{aligned}
& N_{i j} \approx 0 \\
& N_{i i} \approx 0
\end{aligned}
$$$$
B_{i j}=Y_{i j} \sin \theta_{i j}
$$$$
B_{i i}=Y_{i i} \sin \theta_{i i}
$$$$
Q_{i}=\sum_{j=1}^{n}\left|V_{i} V_{j} Y_{i j}\right| \sin \left(\delta_{j}-\delta_{i}+\theta_{i j}\right)
$$

Untuk $\mathrm{J} 2:$$$
j \neq 1
$$

Untuk $\mathrm{J}_{3}$ :

$$
\begin{aligned}
& J_{i j} \approx 0 \\
& J_{i i} \approx 0
\end{aligned}
$$


Untuk $\mathrm{J}_{4}$ :

$$
\begin{aligned}
& L_{i j}=\frac{\partial Q_{i}}{\partial\left|V_{j}\right|}=-\left|V_{i} V_{j} Y_{i j}\right| \sin \left(\delta_{j}-\delta_{i}+\theta_{i j}\right) \\
& =-\left|V_{i} V_{j}\right| \sin \left(\delta_{j}-\delta_{i}\right) \cdot B_{i j} \\
& L_{i j} \frac{\partial Q_{i}}{\partial\left|V_{i}\right|}\left|V_{i} V_{j} Y_{i i}\right|-\sin \theta_{i i} \sum_{\substack{j=1 \\
j \neq 1}}^{n}\left|V_{i} V_{j} Y_{i j}\right| \sin \left(\delta_{j}\right. \\
& \left.\delta_{i}+\theta_{i j}\right) \\
& =\frac{\partial Q_{i}}{\partial\left|V_{j}\right|}=-\left|V_{i} V_{j} Y_{i j}\right| \sin \theta_{i i}+Q_{i} \\
& =\frac{\partial Q_{i}}{\partial\left|V_{i}\right|}=-\left|V_{i}^{2}\right| \cdot B_{i i}+Q_{i} \\
& \operatorname{Dimana}_{i j}=Y_{i j} \sin \theta_{i j} \\
& B_{i i}=Y_{i i} \sin \theta_{i i} \\
& Q_{i}=\sum_{\substack{j=1 \\
j \neq 1}}^{n}\left|V_{i} V_{j} Y_{i j}\right| \sin \left(\delta_{j}-\delta_{i}+\theta_{i j}\right)
\end{aligned}
$$

Dalam format iterasi dapat kita tulis :

$$
\begin{aligned}
& \Delta P^{k}=H^{k} \cdot \Delta \delta^{k+1} \\
& \Delta Q^{k}=L^{k} \cdot \Delta V^{k+1}
\end{aligned}
$$

\subsection{Static Var Compensator}

Untuk permasalahan dalam memenuhi kebutuhan daya reaktif pada seluruh sistem transmisi daya listrik dapat menjaga kestabilan tegangan. Aspek dari perencanaan jaringan harus mereprentasikan kompensasi daya reaktif yang cukup. Kebutuhan kompensasi daya reaktif dengan mengoptimalkan peralatan kompensator guna menjaga mutu tegangan, peralatan tersebut adalah SVC (Static Var Compensator). Metode yang diperlukan untuk dapat mengoptimalkan penentuan lokasi dan kapasitas SVC, menggunakan metode optimasi multiobjektif, Algoritma Genetika dipilih sebagai metode pemecahan

Pada sistem transmisi maupun distribusi sebagian besar beban menyerap daya reaktif. Perubahan beban dan faktor daya menyebabkan variasi ampitudo tegangan, dan menyebabkan turunnya performansi sistem sehingga terjadi undervoltage dan overvoltage dan bisa mengakibatkan kerusakan pada peralatan listrik. Level control tegangan dilakukan untuk mengontrol produksi penyerapan dan aliran daya reaktif pada semua level dalam sistem pembangkitan hingga ke konsumen, semua peralatan SVC terhubung permanen pada sistem kelistrikan jaringan transmisi dan distribusi, untuk mendukung control tegangan dengan memodifikasi karateristik jaringan. SVC digunakan untuk mengontrol tegangan dan daya reaktif. Kontrol cepat daya reaktif perlu dipertahankan selama sistem beroperasi. Kontrol atau kendali daya reaktif pada SVC membantu menjaga profil tegangan sistem selama perubahan kondisi beban. Saluran transmisi dan peralatan-peralatan yang terhubung dengan jaring tersebut secara bersama-sama membentuk medan listrik, sebagaimana medan magnet yang tergantung pada aliran arus. Saat terbentuk, medan-medan ini, energi yang tersimpan kembali akan dilepaskan saat sistem collapse. Terlepas dari energi yang terbuang pada komponen resistif, seluruh peralatan penghubung energi, termasuk trafo dan peralatan konverter energi (seperti motor dan generator), beroperasi sesuai dengan basis kapasitas energi yang disimpan dan yang dilepaskan.

Dalam bentuk fasor, daya kompleks dalam jaring diperlihatkan pada Gambar 1. (a) persamaan dinyatakan sebagai :

$$
\begin{aligned}
& \mathrm{S}=\mathrm{V} . \mathrm{I} \\
& \mathrm{S}=\mathrm{P}+\mathrm{jQ}=\mathrm{VI} \cos \emptyset+\mathrm{j} \mathrm{V} . \mathrm{I} \sin \emptyset
\end{aligned}
$$

P disebut daya aktif, yang diukur dalam watts (W), dan $\mathrm{Q}$ disebut daya reaktif, yang dinyatakan dalam (Var) sedangkan S disebut daya semu (VA). Daya reaktif penting dalam menciptakan medan hubung (coupling field) yang dibutuhkan oleh peralatan energi. Medan hubung ini merupakan tegangan dan arus bermuatan pada sirkuit, tetapi tidak menimbulkan suatu konsumsi daya aktif rata-rata, pada kenyataannya merupakan komponen yang penting di seluruh jaring daya listrik. Di dalam jaring berdaya listrik tinggi, daya aktif dan reaktif diukur dalam megawatt (MW) dan megavar (MVAR).
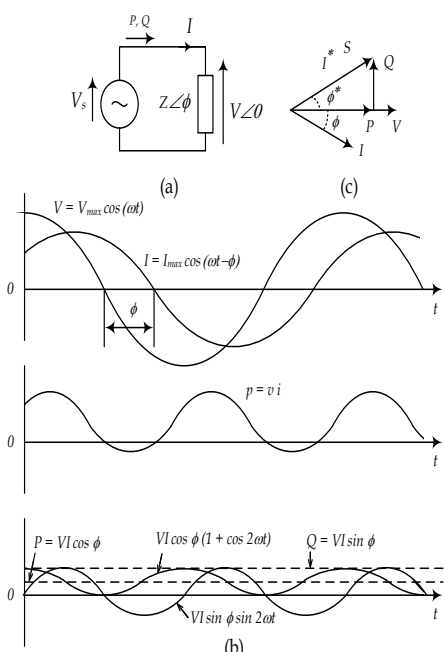

(b)

Gambar 2. a. Rangkaian pengganti

b. Bentuk gelombang tegangan serta daya sinusoidal c. Sistem phasor

sederhana dapat dilihat pada Gambar 2.(a), dimana tegangan sumber Vs, Impedansi saluran Xs dilihat Hubungan sistem daya listrik dengan rangkaian pengganti serta bentuk gelombang dan phasornya ditunjukkan Gambar 1.(a-c).

Pengaturan tegangan dari SVC dari rangkaian dari terminal tegangan SVC. Gambar 2.(b) 
memperlihatkan phasor diagram pengaturan daya reaktif dan induktif SVC. Sedangkan Gambar 2.(c) memperlihatkan karateristik dari kondisi sistem dan SVC.

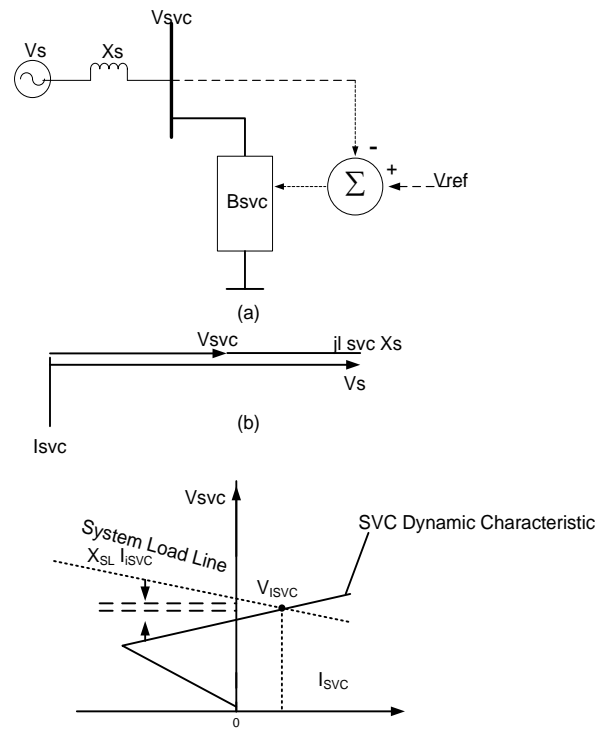

Gambar 3. Pengaturan tegangan dari SVC

Keterangan :

$\mathrm{B}_{\mathrm{svc}}=$ Supceptansi SVC

$\mathrm{V}_{\text {ref }}=$ Tegangan referansi bus SVC

$\mathrm{I}_{\mathrm{svc}}=$ Arus reaktif / Capasitif SVC

$\mathrm{V}_{1 \mathrm{svc}}=$ Tegangan pengaturan $\mathrm{SVC}$

$\mathrm{X}_{\mathrm{S}}=$ Reaktansi saluran

$\sum=$ Penjumlahan

\subsection{Algoritma Genetika}

Algoritma Genetika adalah metode pencarian algoritma didasarkan pada mekanika seleksi alam dan genetik [9].

Dalam metode Algoritma Genetika, ada sekumpulan individu (disebut Populasi) untuk suatu permasalahan-dalam hal ini perhitungan aliran daya dinyatakan dalam bentuk bilangan real, yang menyusun gen-gen pembentuk kromosom tersebut. Populasi dibentuk dari pembangkitan secara acak dan selanjutnya dipilih melalui prosedur operasi Genetika yang terdiri dari Seleksi, Crossover, Mutasi. Hasil dari Mutasi dievaluasi menggunakan fungsi fitness untuk menentukan kromosom mana yang terpilih diikutkan proses perulangan hingga mencapai nilai yang diinginkan sekaligus menghentikan perulangan pada nilai tertentu pada suatu kriteria berhenti yang telah ditetapkan sebelumnya (dapat berupa suatu nilai tertentu atau pada generasi tertentu).

Tujuan penempatan optimal peralatan SVC, menemukan lokasi pada sistem, parameterparameter yang perlu diperhatikan adalah batasan tegangan pada bus dan range kerja SVC.

$\mathrm{Vmin} \leq \mathrm{Vi} \leq \mathrm{Vmax}$
$\mathrm{V} \min =0,95 \mathrm{pu}$ dan $\mathrm{V} \max =1.05 \mathrm{pu}(2.11)$ Qsvc $=$ Qmin $\sim$ Qmax

Sedangkan range kerja

SVC antara -80 Mvar dan 80 Mvar

Algoritma Fast decoupled adalah metode yang digunakan dalam menentukan aliran daya.

Proses AG mengikuti aturan berikut [4].

1. Tentukan inisial populasi (biasanya string dibangkitkan acak)

2. Evaluasi seluruh individu (aplikasikan beberapa fungsi atau formula individu)

3. Menyeleksi populasi baru dari populasi awal berdasar nilai fitnes dari individu yang diberikan oleh fungsi evaluasi.

4. Aplikasikan operator genetika seperti mutase

5. dan pindah silang untuk tiap anggota populasi untuk mendapatkan pemecahan baru.

6. Evaluasi individual baru yang terbentuk.

7. Ulangi langkah 3-6 (satu generasi) hingga terminasi kriteria memuaskan (biasanya berbentuk nomor generasi tertentu

\section{HASIL DAN PEMBAHASAN}

Model saluran yang dipergunakan dalam penelitian ini adalah data dari sistem 30 bus IEEE. Data tersebut terdiri dari 30 bus dan 24 saluran, 1 slack bus, 4 kontrol tegangan bus 2 pusat pembangkit.

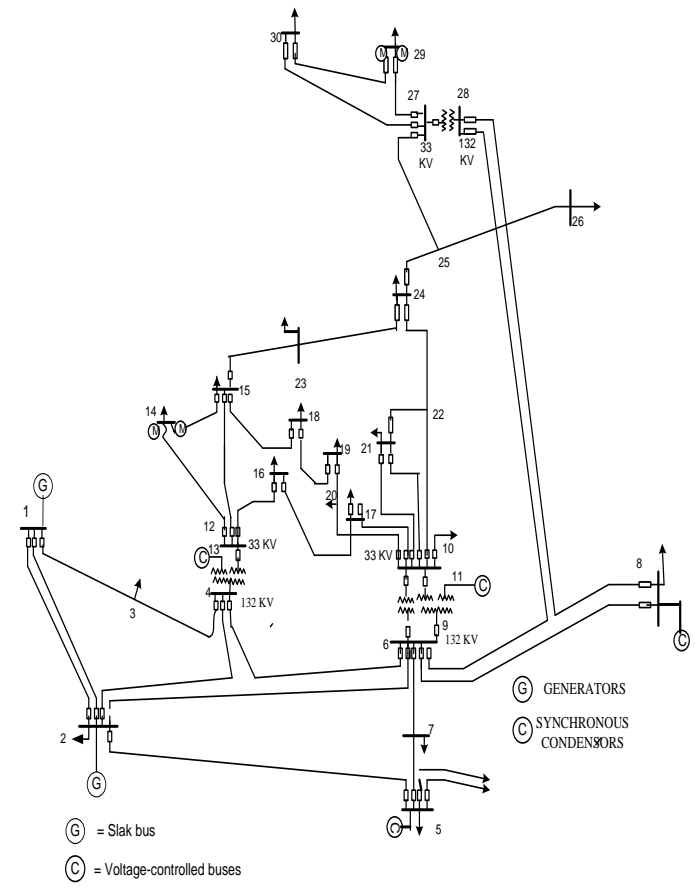

Gambar 4. Data 30 Bus IEEE

Single line diagram untuk sistem 30 bus IEEE dapat dilihat pada Gambar 4. 
Berdasarkan hasil simulasi yang dilakukan melalui program MATLAB Versi 2016a Implementasi GA dari metode yang diusulkan dalam penempatan peralatan SVC dipilih berdasarkan hasil analisis aliran daya yang mengalami penurunan tegangan atau hasil analisis tegangan yang melanggar fungsi objektif. Hasil-hasil data aliran daya menggunakan metode Fast decoupled sebelum optimasi atau penambahan SVC diberikan pada Tabel 1.

\begin{tabular}{|c|c|c|c|c|}
\hline \multicolumn{5}{|c|}{ Tabel 1: Tegangan sebelumOptimasi } \\
\hline No & $\begin{array}{l}\text { Voltag } \\
\text { e } \\
\text { Mag }\end{array}$ & $\begin{array}{l}\text { Angle } \\
\text { Degree }\end{array}$ & $\begin{array}{c}\text { Injecte } \\
\text { d } \\
\text { Mvar }\end{array}$ & $\begin{array}{c}\text { SVC } \\
\text { MVa } \\
\text { r }\end{array}$ \\
\hline 1 & 1.06 & 0.000 & 0 & 0 \\
\hline 2 & 1.003 & -5.135 & 0 & 0 \\
\hline 3 & 0.958 & -7.637 & 0 & 0 \\
\hline 4 & 0.944 & -9.417 & 0 & 0 \\
\hline 5 & 0.915 & -14.528 & 0 & 0 \\
\hline 6 & 0.944 & -11.504 & 0 & 0 \\
\hline 7 & 0.923 & -13.369 & 0 & 0 \\
\hline 8 & 0.96 & -12.644 & 0 & 0 \\
\hline 9 & 0.986 & -15.308 & 0 & 0 \\
\hline 10 & 0.954 & -17.343 & 19.000 & 0 \\
\hline 11 & 1.082 & -15.308 & 0 & 0 \\
\hline 12 & 0.936 & -15.917 & 0 & 0 \\
\hline 13 & 0.936 & -15.917 & 0 & 0 \\
\hline 14 & 0.905 & -16.534 & 0 & 0 \\
\hline 15 & 0.906 & -16.85 & 0 & 0 \\
\hline 16 & 0.935 & -16.891 & 0 & 0 \\
\hline 17 & 0.942 & -17.47 & 0 & 0 \\
\hline 18 & 0.893 & -17.448 & 0 & 0 \\
\hline 19 & 0.903 & -18.002 & 0 & 0 \\
\hline 20 & 0.915 & -17.922 & 0 & 0 \\
\hline 21 & 0.935 & -17.803 & 0 & 0 \\
\hline 22 & 0.935 & -17.767 & 0 & 0 \\
\hline 23 & 0.888 & -17.057 & 0 & 0 \\
\hline 24 & 0.905 & -17.815 & 4.3 & 0 \\
\hline 25 & 0.9 & -17.41 & 0 & 0 \\
\hline 26 & 0.88 & -17.949 & 0 & 0 \\
\hline 27 & 0.907 & -16.829 & 0 & 0 \\
\hline 28 & 0.939 & -12.188 & 0 & 0 \\
\hline 29 & 0.85 & -17.392 & 0 & 0 \\
\hline 30 & 0.854 & -19.114 & 0 & 0 \\
\hline
\end{tabular}

Setelah penambahan daya reaktif SVC yang diinjeksikan pada bus 17, 18, 19 dan 30 sebesar 70 Mvar profill tegangan mengalami perubahan hampir tiap bus sehingga hasil dapat dilihat pada Tabel 2 setelah penambahan peralatan SVC

\begin{tabular}{|c|c|c|c|c|}
\hline \multicolumn{5}{|c|}{ Tabel 2: Tegangan setelah Optimasi } \\
\hline Bus & $\begin{array}{l}\text { Voltag } \\
\text { e } \\
\text { Mag }\end{array}$ & $\begin{array}{l}\text { Angle } \\
\text { Degree }\end{array}$ & 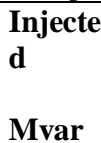 & $\begin{array}{l}\text { SVC } \\
\text { MVa } \\
\text { r }\end{array}$ \\
\hline 1 & 1.06 & 0,000 & 0 & 0 \\
\hline 2 & 1.023 & -5.326 & 0 & 0 \\
\hline 3 & 0.984 & -7.772 & 0 & 0 \\
\hline 4 & 0.976 & -9.552 & 0 & 0 \\
\hline 5 & 0.942 & -14.272 & 0 & 0 \\
\hline
\end{tabular}

\begin{tabular}{|c|c|c|c|c|}
6 & 0.974 & -11.468 & 0 & 0 \\
7 & 0.953 & -13.208 & 0 & 0 \\
8 & 0.98 & -12.368 & 0 & 0 \\
9 & 1.036 & -14.893 & 0 & 0 \\
10 & 1.039 & -16.63 & 19.000 & 0 \\
11 & $\mathbf{1 . 0 8 2}$ & -14.893 & 0 & 0 \\
12 & 1.025 & -15.372 & 0 & 0 \\
13 & 1.025 & -15.372 & 0 & 0 \\
14 & 1.006 & -16.044 & 0 & 0 \\
15 & 1.014 & -16.65 & 0 & 0 \\
16 & 1.03 & -16.369 & 0 & 0 \\
17 & 1.042 & -17.012 & 0 & $\mathbf{2 0}$ \\
18 & 1.042 & -18.204 & 0 & $\mathbf{2 0}$ \\
19 & 1.05 & -18.574 & 0 & $\mathbf{2 0}$ \\
20 & 1.047 & -18.139 & 0 & 0 \\
21 & 1.023 & -17.031 & 0 & 0 \\
22 & 1.023 & -17.006 & 0 & 0 \\
23 & 0.992 & -16.691 & 0 & 0 \\
24 & 0.999 & -17.139 & 4.3 & 0 \\
25 & 0.991 & -16.709 & 0 & 0 \\
26 & 0.973 & -17.152 & 0 & 0 \\
27 & 0.994 & -16.173 & 0 & 0 \\
28 & 0.974 & -12.169 & 0 & 0 \\
29 & 0.962 & -17.118 & 0 & 0 \\
30 & 0.984 & -19.086 & 0 & $\mathbf{1 0}$ \\
& & & & \\
& & & & \\
\hline
\end{tabular}

Grafik tegangan sebelum optimasi penempatan optimal SVC memperlihatkan kondisi tegangan pada tiap-tiap bus. Pada bus 1 dan 11 mengalami kelebihan tegangan sebesar 1,082, pada bus 2, 3, 8, 9 dan 10 kondisinya normal sedangkan pada bus 4,5 , $6,7,12,13,14,15,16,17,18,19,20,21,22,23,24$, $25,26,27,28,29$ dan 30 mengalami penurunan tegangan.

Gambar 5, merepresentasikan proses kerja dari metode CSA. Berdasarkan gambar tersebut dapat diketahui bahwa rugi-rugi minimum dapat diperoleh setelah injeksi peralatan SVC dengan penambahan daya sebesar 70 Mvar pada bus 17, 18, 19 dan 30 menghasilkan profil tegangan pada tiap-tiap bus menjadi lebih baik. Dari grafik perbandingan tegangan dapat dilihat setelah injeksi tegangan yang mengalami perubahan terjadi pada bus $4,6,7,12$, $13,14,15,16,17,18,19,20,21,22,23,24,25,26$, 27, 28, 29 dan 30 .

Berdasarkan evaluasi rugi-rugi daya pada sistem. Penempatan peralatan SVC dapat dicapai dengan baik. Hasil-hasil tersebut dapat dilihat Gambar 6 dan 7 . 


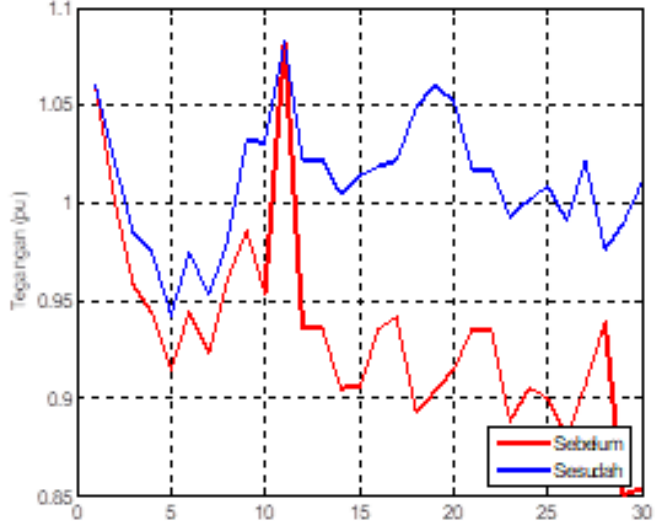

Gambar 5, merepresentasikan proses kerja dari metode CSA.

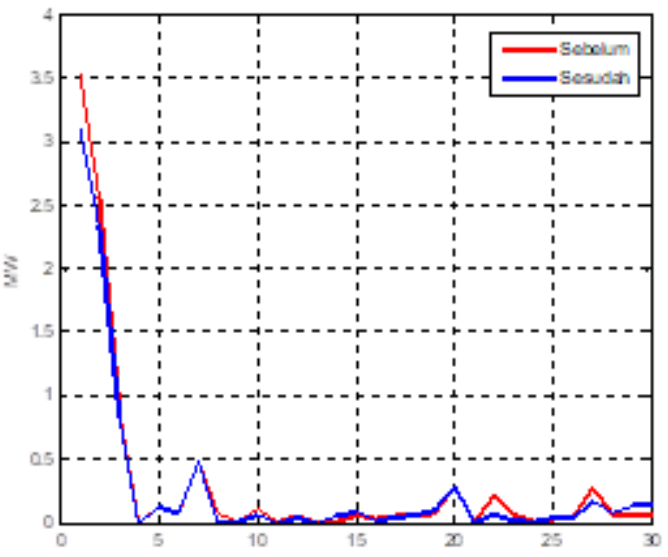

Gambar 6. Perbaikan daya Aktif sebelum dan sesudah optimasi pemasangan SVC.

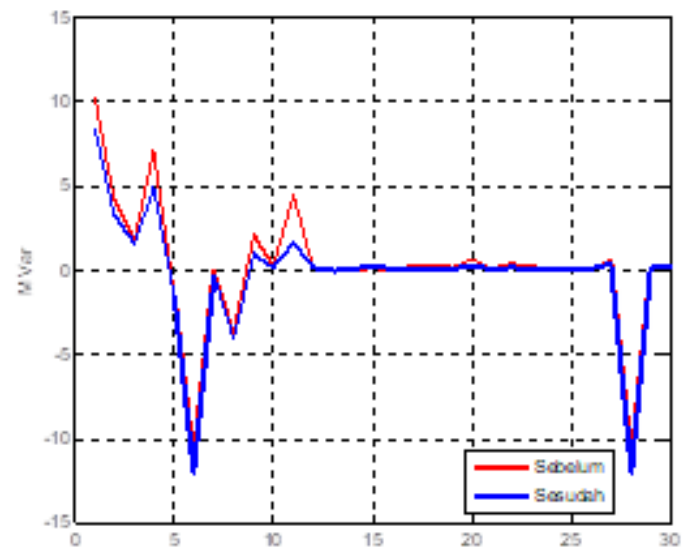

Gambar 7. Perbaikan daya Reaktif sebelum dan sesudah optimasi pemasangan SVC

\subsection{Analisis}

Dari hasil simulasi yang ditunjukkan pada Gambar 8 dan 9 menunjukkan bahwa :
1. Penempatan SVC untuk mengontrol tegangan sehingga profil tegangan pada tiap bus lebih baik dari sebelum adanya pemasangan SVC.

2. Penempatan SVC mengoptimalkan penyaluran daya reaktif pada sistem yang mengalami perubahan akibat undervoltage dan overvoltage, sehingga memenuhi kebutuhan beban.

3. Pembangkitan dan penyaluran daya pada sistem yang baik menghasilkan nilai ekonomis yang baik pula.

\section{Kesimpulan}

Berdasarkan pengamatan dan analisis peneltian pada sistem 30 bus IEEE, hasil penelitian ini dapat dibuat kesimpulan sebagai berikut :

1. Hasil simulasi yang dicapai dalam penempatan peralatan SVC berdasarkan metode kombinasi fungsi objektif dengan bermacam batasan-batasan dipertimbangkan digunakan dalam menyeleksi bus-bus yang tepat untuk penempatan SVC.

2. Hasil dari komputasi yang diusulkan penempatan SVC sebagai control tegangan dengan injeksi SVC sebesar 70 Mvar pada bus 17, 18, 19, dan 30 dapat memperbaiki tegangan, sehingga memenuhi kebutuhan daya reaktif.

3. Peformansi komputasi yang dapat dicapai menunjukan suatu peningkatan hasil yang memuaskan. Hal ini dapat dilihat pada kondisi sebelum optimasi penempatan SVC tegangan terendah pada bus 29 sebesar 0,850 pu sedangkan sesudah optimasi penempatan SVC tegangan terendah terdapat pada bus 5 dengan tegangan sebesar $0,942 \mathrm{pu}$.

\section{Daftar Pustaka}

[1] Arlenny, Optimation of Capacitor Bank Placement in Electric Network Using Genetic Algorithm .Jurnal URICSE.2019

[2] Damis Hardiantono, Perencanaan Penempatan FACTS Optimal Menggunakan Algoritma . Jurnal Ilmiah Mustek Anim Ha Vol.1 No. 2, Agustus 2012

[3] Enrique Acha, Claudio R. Fuerte-Esquivel, Hugo Ambriz-Pe rez,Ce sarAngeles-Camacho.FACTS Modelling and Simulation inPowerNetworks. New York: John Wiley \& Sons, 2004

[4] Imam Robandi Artificial Intelegence “ Mengupas Rekayasa Kecerdasan Tiruan “ Yogyakarta: Penerbit Andi 2019

[5] Syarifil Anwar, Hadi Suyono dan Harry Soekotjo "Optimisasi Penempatan SVC untuk Memperbaiki Profil Tegangan dengan Menggunakan Algoritma Genetika" Jurnal Elektro ELTEK Vol. 3, No. 1, April 2012

[6] Othman, Ahmed,Mohamed.Enhancing the Performance of Flexible ACTransmission 
Systems.Aalto University publication series.Helsinki,Finland.2011

[7] Stevenson, William D., and John J. Grainger.Power System Analysis.Singapore:Mc Grow Hill.1994

[8] Saadat H 1999 Power System Analysis Series in Electrical and Computer Engineering Grainger McGraw-Hill

[9] Swarup K S 2005 Genetic algorithm for optimal capacitor allocation in radial distribution systems Proceedings of the 6th WSEAS Int. Conf. on Evolutionary Computing Lisbon Portugal June 16-18, 152-159

[10] Saonerkar A K and Bagde B Y 2014 Optimized DG placement in radial distribution system with reconfiguration and capacitor placement using genetic algorithm IEEE International Conference on Advanced Communications, Control and Computing Technologies, 10771083

[11] Stevenson, William D., and John J. Grainger.Power System Analysis, Singapore: Mc Grow Hill, 1994 